\title{
Bronislava Kasáčová
}

\section{Daniela Guffová}

\section{OPINIONS OF SLOVAK ACADEMIC STAFF AND STUDENTS ON THE PROFESSIONAL COMPETENCES OF ACADEMIC TEACHERS}

\begin{abstract}
The paper is a result of comparative study conducted over the period 2017-2018 within the International Visegrad Fund project No. 21720008. Four countries are included in the project, namely Ukraine, Poland, Czech Republic and Slovak Republic. The opinions of university teachers and students on the competences of academic teachers are investigated and compared within the study. The specifics of Slovak view and legislation of professional competences are presented in the paper. Moreover, the analysis of data obtained in Slovak universities based on comparison of teachers' and students' opinions on academic teachers' competences are described.
\end{abstract}

Key words: academic teachers, competence, comparative study, professional competence, professional research.

๑ B Bronislava Kasáčová, Daniela Guffová, 2018

\section{Introduction}

Since the beginning of $21^{\text {st }}$ century, the topic of professional competenceshas resonated in particular scientific disciplines as well as in Slovak legislation. The long-term process within the European Union leads to equalization of qualification frameworks that are anchored in European qualification framework. Also in Slovakia, the transformation process of professional requirements has started in various professions in accordance with the requisites of the European Union. This was done to unify professional standards in line with the Slovak accession to the European Union on May $1^{\text {st }}, 2004$. However, the processes of legislation changes had been in progress also during the transition period. Following the example of the research within Visegrad Fund project No. 21720008 we can see that it is important to have corresponding qualification frameworks within different countries which is for example equivalent in Slovak and Czech Republic. Analogous equivalents are used in Poland as there were bilateral agreements of ministries of Slovak, resp. Czech Republic and Poland on acceptance of university qualifications. However, it is slightly more complicated to compare this criteria considering the qualification with Ukraine.

A formulation of professional competence profiles as binding standards denoting the condition of entry and pursuit of professions was the basic change in professional requirements in Slovakia. In the same time, the legislative support for the teaching profession was aimed at the continual lifelong development as a demand for maintaining the professional condition. Two main attitudes: 1. academic-research and 2. legislative-executive were applied to formulation of professional standards in international contexts. The academicresearch approach was represented by professional research (professiography) and its comparison with the current requirements regarding the needs of practice and science development. The legislativeexecutive attitude followed the European qualifications framework (EQF) and adopted the statutory regulations. It is worth mentioning that in the research approach was not applied in some professions. This led to interference between the declared requirements and reality (professional status, number of experts meeting the requirements, professional expertise, balance between the reality and the declared requirements). Thus it has to be stated that the national traditions and specifics has to be respected within the process of international unification of legislative and professional requirements on professional competences.

A good example of standardization in Slovakia is the preparation of Act on pedagogical employees No. 317/2009 Coll. which was built on a rigorous professiographic research (Kasáčová, 2011) in coordination with the preparation of law and related legislation (including transitional provisions) as well as on public discussion. The act includes theprofessionalcompetencestandardfor allteaching positions except for academic teachers. These are legislatively bound by the Act on universities No. 131/2002 Coll. from February $21^{\text {st }}$, 2002 that is supplemented by other laws.

Nowadays, there is a strong debate about the modification of the Act as it has several disadvantages. One of them is that it includes only brief formulation of rights and duties of academic teachers. 
Apart from that, the modern view of professional competences completely absents. However, these disadvantages are caused by the time when the Act on pedagogical employees No. 131/2002 Coll. was released, in which the requirements for professional competences were not discussed.

The recent effort to apply a competence based approach is in charge of every university. However, in the context of growing competition universities consider the quality of academic teacher in all dimensions to be of the highest importance. Because of the decreasing student population, high competition has risen among the universities. In countries with comparable population (Slovenia, Finland, Netherlands, Belgium) there are 5-10 universities. However, there are 20 public schools, 3 state schools and 12 private schools of higher education in Slovakia and 14134 academic teachers at Slovak universities ${ }^{1}$. This fact led to the need to investigate the academic teacher competences.

Blašková et al (2014) published theoretical and empirical investigations of academic teacher competences based on international basis. These were originally formulated according to the project DEQUA (Development of culture quality at the University of Žilina based on European standards of higher education) in ten categories (Blašková et al, 2014, p. 459):

1. Moral and ethical competence.

2. Role model competence.

3. Technical (expert) competence.

4. Mature personality competence.

5. Scientific competence.

6. Critical thinking competence.

7. Acclaimed author's competence.

8. Communication competence.

9. Excellent teaching competence.

10. Motivation competence.

The authors assessed the views on these competences at larger sample of students (439 males and 247 females), collecting both positive and negative characteristics. They created a competence model consisting of 8 categories in which they identified both polarities of performance that can be observed and consecutively revalidated by behavioural indicators (Blašková et al, 2014, pp. 463-464). It is regrettable that this model is only theoretically applied and the ministry prefers evaluation based solely on outputs and performance.

Therefore we decided to participate in research within Visegrad Fund project and in the international team (Ukraine, Czech Republic, Slovak Republic, Poland) investigate and compare the opinions of academic teachers and students on the importance of competences of academic teachers. These opinions were monitored in 2018 using e-questionnaires for students and teachers. In this text we present research findings from a national perspective.

\section{A description of the national analysis}

The objective of the research was to find out opinions of respondents on competences of academic teachers. The research data in the Slovak cohort of the research sample was collected in the period of January - February 2018.

The participants of the survey were asked to fill in the electronic version of a questionnaire in which we respected the English version of the common Ukraine-Czech-Polish-Slovak version of research tool. The respondents indicated their opinions on importance of particular competences on 4-point scale. However, in order to satisfy the assumptions of $\chi^{2}$ test of independence, the answers claiming More no than Yes and No were united in one category No.

The Slovak part of research sample consisted of 67 academic teachers and 82 students. Distributions of teacher respondents by gender, qualification, age and length of teaching experience are presented in Table 1.

Table 1

IDENTIFICATION OF THE TEACHER PARTICIPANTS

\begin{tabular}{|c|c|c|}
\hline \multicolumn{3}{|c|}{ Participants [Number - \% of all] $67-100 \%$} \\
\hline \multicolumn{2}{|c|}{ Male $-26,9 \%$} & Female $\quad-73,1 \%$ \\
\hline $\mathrm{PhD} \quad 38-56,7 \%$ & Associate professor $14-20,9 \%$ & Professor $-22,4 \%$ \\
\hline Practice $<10$ years $17-25,4 \%$ & 11 years $<$ Practice $<20$ years $21-31,3 \%$ & Years $<$ Practice $-43,3 \%$ \\
\hline $\begin{array}{c}25-40 \text { years } \\
24-35,8 \%\end{array}$ & $\begin{array}{c}41-55 \text { years } \\
21-31.3 \%\end{array}$ & $\begin{array}{c}\text { more than } 71 \text { years } \\
0-0 \%\end{array}$ \\
\hline
\end{tabular}

${ }^{1}$ https://www.portalvs.sk/regzam/stats/?date=2018-06-30 (31.6.2018) 
Distributions of student respondents by gender and year of study are presented in Table 2.

Results and analysis of national finds in Slovakia

A chi-square test of independence was conducted between position and opinion on academic teacher's competences within three profiles: professional-pedagogical, social-personal and academic. There was no statistically significant association between position and opinion on academic teacher's competences within:

1) professional-pedagogical profile, $\quad \chi 2(2)=$ $0,040, p=0,980$. The association was small (Cramer's V $=0,016$ )

2) social-personal profile, $\quad \chi 2(2)=0,369$, $\mathrm{p}=0,831$. The association was small (Cramer's $\mathrm{V}=0,050)$.

3 ) academic profile, $\chi 2(2)=0,415, p=0,813$. The association was small (Cramer's V $=0,053$ ).

Furthermore, Mann-Whitney $U$ test was run to determine if there were differences in opinions about a university teacher's competences between teachers and students in all three profiles. Although no statistically significant difference was found between opinions of teachers and students in any of the profiles in general, there were statistically significant differences in several items. The comparisons of the answers provided by Slovak academic teachers and university students concerning their opinion on academic teacher competences revealed significant differences in the following items:

- Professional-pedagogical profile:

$1)$ the use of fundamental knowledge and permanent updates of the content $(Z=-2,023$; $\mathrm{p}=0,043)$;

2) the satisfaction with professional results $(\mathrm{Z}=-2,326 ; \mathrm{p}=0,020)$;

3 ) the ability to work with information in global network based on critical analysis $(Z=-2,664$; $\mathrm{p}=0,008)$.

- Social-personal profile:

4) the ability to keep to the rules of professional ethics with all subjects of the educational process $(\mathrm{Z}=-2,546 ; \mathrm{p}=0,011)$;

$5)$ adherence to standards of academic integrity $(\mathrm{Z}=-2,708 ; \mathrm{p}=0,007)$;

6) the knowledge of one's civil rights and duties and upholding to them $(Z=-2,351 ; p=0,019)$.

- Academic profile:

7) presentation of the results of scientific activities to international community $(\mathrm{Z}=-4,879$; $\mathrm{p}<0,0005$ );

8) the proficiency in modern methodology and methodology of research in the field of higher education $(Z=-2,684 ; p=0,007)$.

Add. 1 Teachers considered the ability to use fundamental knowledge in educational process, the achievement of modern science and constant updates of the content of education courses to be more important than students.

Table 2

IDENTIFICATION OF THE STUDENT PARTICIPANTS

\begin{tabular}{|c|c|c|c|c|c|}
\hline \multicolumn{6}{|c|}{ Participants [Number $-\%$ of all] $\quad 82-100 \%$} \\
\hline \multicolumn{3}{|c|}{$\begin{array}{c}\text { Male } \\
3-3,7 \% \\
\end{array}$} & \multicolumn{3}{|c|}{$\begin{array}{c}\text { Female } \\
79-96,3 \%\end{array}$} \\
\hline $\begin{array}{c}\text { Year } 1 \\
4-4,9 \%\end{array}$ & $\begin{array}{c}\text { Year } 2 \\
32-39,0 \%\end{array}$ & $\begin{array}{c}\text { Year } 3 \\
7-8,5 \%\end{array}$ & $\begin{array}{c}\text { Year } 4 \\
36-43,9 \%\end{array}$ & $\begin{array}{c}\text { Year } 5 \\
3-3,7 \%\end{array}$ & $\begin{array}{l}\text { Year } 6 \\
0-0 \%\end{array}$ \\
\hline
\end{tabular}

Table 3

\section{CROSS TABULATION OF POSITION AND OPINION ON ACADEMIC TEACHER COMPETENCES IN THREE PROFILES}

\begin{tabular}{|c|c|c|c|c|c|c|}
\hline Profile & \multicolumn{2}{|c|}{ Professional-pedagogical } & \multicolumn{2}{|c|}{ Social-personal } & \multicolumn{2}{|c|}{ Academic } \\
\hline Opinion Position & Teacher & Student & Teacher & Student & Teacher & Student \\
\hline Yes & 25 & 30 & 35 & 44 & 23 & 25 \\
\hline Rather Yes than No & 30 & 38 & 27 & 30 & 30 & 41 \\
\hline No & 12 & 14 & 5 & 8 & 14 & 16 \\
\hline
\end{tabular}


Add. 2 On the other hand, students considered the satisfaction with the results of professional activity to be more important than teachers. They think that it is crucial for academic teacher to be satisfied with the results of his/her professional activities. However, more than fifth of teachers do not see satisfaction with the results of their work to be important. Nevertheless, it cannot be misinterpreted in the sense that teachers do not consider the satisfaction with the results of their work as necessary. On the contrary, they realize the reality that the duties are more important than the feeling of satisfaction.

Add. 3 Moreover, teachers think that critical analysis of information from global networks is relevant part of their work. Nonetheless, only quarter of students think that it is of utmost importance and quarter of students do not see critical analysis as needed in the work of academic teacher. In this case the research should be complemented by a qualitative analysis of the concept of critical analysis.

Add. 4 Although teachers strongly consider observance of the ethical principles to be essential, students are not so strongly convinced that it is so important to follow them. The highest number of teachers claimed that observance to the rules of professional ethics is very important. It is surprising that students do not attribute such high importance to this competence.

Add. 5 Teachers also considered the adherence to standards of academic integrity to be more important than students. Three quarters of teachers are convinced that the adherence to academic integrity's standards is essential competence of academic teacher. Also students consider it to be important, but not as strongly as teachers do.

Add. 6 On the other hand, students considered the knowledge of civil rights and duties and upholding to them basing on valid laws to be more important than teachers. The highest number of students consider the awareness and application of civil rights to be of utmost importance for academic teacher.

Add. 7 Students do not recognize the importance of scientific results' presentation to international community as strongly as teachers do. More than third of them think it is not necessary. Overall, the greatest difference between the views on its importance among students and teachers was shown in this competence.

Add. 8 Apart from that, more students than teachers think that proficiency in modern methodology and methodology of research in the field of higher education is needed in the work of academic teacher.
In all the other items no statistically significant differences were found between opinions of teachers and students. These include the use of innovative learning technologies and creation of distance learning courses. Although both teachers and students consider the implementation of innovative technologies to be necessary for academic teacher, neither teachers nor students see creation of distance learning as very important. In the era of e-learning this is quite surprising. Also the correspondence between teachers and students is interesting. We suppose that this is caused by preference of personal contact between teacher and student in our conditions as the University emphasizes it in the quality policy.

Another item in which opinions of teacher and students coincided was the one on the use of various means of communication and interactive coordination or organization of group and collective activities. Both teachers and students recognize the use of various means of communication as important. Students express their conviction more clearly than teachers. However, almost fifth of teachers do not consider interactive coordination or organization of group and collective activities to be essential in the work of academic teacher. We think that more students realize that the ability to work in team is important in their future work as the ability to cooperate is nowadays one of the mostly required skills. Thus students expressed their opinion that academic teachers should implement cooperative learning within the education.

No statistically significant differences were also found between opinions of teachers and students on the use of research based learning, the use of technology to manage students' self-study, the ability to set and achieve the didactic goals according to SMART technology and the ability to use different technologies to monitor educational outcomes. Teachers considered the ability to create an educational environment that contributes to cognitive activity of students and research based learning to be slightly more important than students. However, both teachers and students see research based learning as quite important educational tool. But more teachers consider it to be of utmost importance.

Only third of teachers and students think that the use of technology to manage students' selfstudy is essential. Moreover, one fifth of teachers and students think that it is not important. Third of teachers are persuaded that the ability to set and achieve the didactic goals according to SMART technology is not necessary. Only quarter of teachers and students are convinced that the use of different 
technologies to monitor educational outcomes is definitely important. Similarly, quarter of teachers and students think that it is not important at all.

Furthermore, opinions of teachers and students on perceiving the younger generation as the generation with special values, restraining negative emotions and overcoming bad mood and encouraging tolerance to differences were not statistically significant different. Both students and teachers consider all these competences to be very important for academic teacher. However, more teachers than students are strongly persuaded that the younger generation should be perceived as a generation with special values and needs by academic teacher. On the other hand, students are slightly more convinced that encouraging tolerance to differences is of utmost importance.

The opinions of teachers and students on understanding the social significance and high responsibility of one's professional activities, openness to communication, aspiration to understanding and solving complex situations and coming to a decision and taking responsibility for success and failures in professional work were not statistically significantly different. The opinions of teachers and students are very similar, both groups are convinced that academic teacher should understand the social significance and her/ his responsibility. Both teachers and students are persuaded that the openness to communication and complex situations' solving are very crucial for academic teachers. Moreover, almost all teachers think that the responsibility for success and failure is important for their work. However, some students claim that academic teachers do not have to be responsible for their success or failure.

There were no statistically significant differences in opinions of teachers and students on providing leadership support for student youth, demonstrating a high level of general and professional culture, ability to present and stand up for own ideas as well as take part in a dialogue and discussion and giving students real opportunities for developing self-management and supporting youth initiatives. Most of the teachers think that academic teacher should support students and demonstrate a high level of general and professional culture. Almost fifth of students do not consider such leadership to be important. Both teachers and students are convinced that presentation of own ideas and participation in a dialogue is one of the most necessary competences in the profile of academic teacher. Almost all teachers and students consider the self-management's development of students to be the academic teacher's responsibility. However, more students see it as the crucial competence of academic teacher.
Besides that, no statistically significant difference was found between opinions of teachers and students on a high motivation to perform professional tasks. We should be aware of the fact that approximately a quarter of students and teachers do not consider motivation to perform professional tasks to be important for academic teacher.

There were no statistically significant differences of opinions of teachers and students on combination of teaching and scientific activities, organization of student's studying process basing on research and organization of research groups on topical issues of science, participation in national and international projects. Both teachers and students agree that educational and scientific activities of academic teacher should be closely related. On the other hand, more than third of students and teachers do not think that participation in projects and organization of research groups is important for academic teacher. This competence, among all, seems to be the least important from the point of view of teachers and students.

Additionally, opinions of teachers and students on participation in the main forms of internationalization of higher education and publishing the results of scientific research in scientometric publications were not statistically significantly different. One fifth of students and teachers do not consider the ability to be involved in the main forms of higher education's internationalization to be important for academic teacher. Only third of students of teachers and students are persuaded that it is of utmost importance. Moreover, almost one third of teachers and students believe that the ability to publish scientific articles in scientometric publication is very important.

Also no statistically significant differences were found between opinions of teachers and students on expertise in the relevant scientific field, conducting expert examinations, preparing reviews, leading a scientific school and promotion of the results of research using an e-portfolio. Most of the teachers and students consider the expertise of academic teacher to be needed in the work of academic teacher. Almost half of them are convinced that it is of the utmost importance. Almost one third of teachers do not see research results' promotion via e-portfolio as relevant competence for academic teacher. On the other hand, almost third of students and teachers think it is of utmost importance.

Opinions of teachers and students on involvement of students in scientific activities, managing of elective scientific club and development a diagnostic tool 
for the analysis of scientific data were not statistically significantly different. More than third of teachers and students are persuaded that involvement of students in scientific activities is not important. On the other hand, approximately one fifth of students and teachers see it as necessary competence. Moreover, more than third of teachers see the development of a diagnostic tool as unimportant. More students than teachers consider this competence to be useful for academic teacher.

Moreover, the in-depth analysis of the data did now show statistically significant differences between the students' respondents regarding their age nor gender in any of the competence profiles in general. Similar results were obtained for teachers' respondents with regard to their qualification, gender, and length of practice or age.

\section{Conclusion}

International cooperation and participation in research projects is a stimulating resource for the development of academic workplaces, i. e. of teachers, researchers, students, processes as well as methods and tools at institutional, personal and processual level of tertiary education. The obtained results seem to confirm that the Slovak students and academic teachers see most of the academic teacher competences to be very important. However, it has to be stated that the research carried out within the project of international cooperation has its limitations, as we studied only small number of academic teachers and students.

Also the research tool has some boundaries. One of the methodological limitations of research tool is that the questionnaire did not investigate the real situation but only opinion of respondents on competences of academic teachers. Another limitation is that the research tool did not deal with professional focus of students and teachers. Moreover, in some statements there were more variables included. Besides that, respondents could not express their neutral opinion. Another momentum that was reflected several times, is the degree of agreement and disagreement with individual items. One respondent wrote: everything is important, but how it is possible that academic teacher is so ideal? This resulted in avoidance of negative side of scale by both teachers and students and production of high amount of positive answers.

The issue of academic teachers and researchers' competences is inseparable from the whole system of evaluation and quality policy of higher education institutions. It is not just a narrow view on academic teachers and requirements which current trends accent. Quality of a teacher cannot be isolated factor as it influences the quality of students, university environment, remuneration system and motivation to work and continuous self-development. It is closely related to the formulation of graduates' profiles of particular study programs and the design of study programs. This follows from the fact that specific study programs require specific types and qualities of academic teachers as theoretical study programs have different characteristics than practically oriented study programs. Naturally, that leads to different requirements on competence profile of academic teacher.

Finally, it is necessary to state that if we want to investigate and compare the professional competences of academic teachers, also the standard positions of academic teachers should be equivalent and comparable.

\section{REFERENCES}

1. Arnon, S., Reichel, N. (2007). Who is the Ideal Teacher? Am I? Similarity and difference in perception of students of education regarding the qualities of a good teacher and of their own qualities as teachers. Teachers and Teaching: Theory and Practice, 13(5), 441-464.

2. Babiaková, S. (2014). Miesto evalvácie v kontinuálnom vzdelávaní učitelov. [Place of Evaluation in Continuous Teacher Education.] In. Malach, J. et. Chmura, M. Diagnostika a evalvace dospělých. Ostrava: PdF OU v Ostravě, 9-28. ISBN 978-80-7564-654-6.

3. Blašková, M., Blaško, R. Kucharčíková, A. (2014). Competences and Competence Model of University Teachers. Procedia - Social and Behavioral Sciences, 159, pp. 457-467. Elsevier Ltd. 2014 1877-0428

4. Blašková, M., Blaško, R., Jankalová, A., Jankal, M. (2014). Key Personality Competences of University Teacher: comparison of requirements defined by teachers and/versus defined by students. Procedia Social and Behavioral Sciences, 114, pp. 466-475. Elsevier Ltd. 2014 1877-0428

5. Duţă, N., Pânişoară, P., Pânişoară, I.O. (2014). The Profile of the Teaching Profession — Empirical Reflections on the Development of the Competences of University Teachers. Procedia - Social and Behavioral Sciences, 140, pp. 390-395. Elsevier Ltd. 2014 1877-0428

6. Fischer, A. W., Schratz, M. (1997). Vedení a rozvoj školy. [Leadership and Development of School] Brno : Paido, $171 \mathrm{~s}$.

7. Gibbs, G., Coffey, M. (2000). Training to Teach in Higher Education: a research agenda. Teacher Development, 4:1, 31-44, DOI: 10.1080/13664530000200103 
8. Guerriero, S. (ed.) (2017). Pedagogical Knowledge and the Changing Nature of the Teaching Profession. Paris: OECD Publishing.

9. Hanesová, D., Saari, S. (2015). Research - Education - Evaluation. Research outputs. Banská Bystrica: PF UMB.

10. Hanesová, D. (2016). Teachers under the Microscope. A review of research on teachers in post-communist region. Bloomington: Authorhouse.

11. Kasáčová, B. et al (2011). Pre-primary and Primary Job Analysis. Banská Bystrica: PF UMB.

12. Koslowski III, F. A. (2006). Quality and Assessment in Context: A brief review. Quality Assurance in Education, 14(3), 277-288.

13. Seberová, A. (2011). Využití smíšené metodologie v profesiografickém výzkumu učitelské profese. [The Use of Mixed Methodology in Profesiographic Research Study of Teacher Profession]. In T. Janík, P. Knecht, \& S. Šebestová (Eds.), Smíšený design v pedagogickém výzkumu: Sborník př́íspěvků z 19. výroční konference České asociace pedagogického výzkumu. (s. 73-79). Brno: Masarykova univerzita.

14. Sonmark, K. et al (2017). Understanding Teachers' Pedagogical Knowledge: report on an international pilot study. OECD Education Working Papers, No. 159, OECD Publishing, Paris.

http://dx.doi.org/10.1787/433332ebd-en

15. Tomengová, A. et al (2017). Pedagogické znalosti a profesionalita učitela. [Pedagogical Knowledge and Teacher Professionality]. Banská Bystrica: Belianum.

16. https://www.portalvs.sk/regzam/stats/?date=2018-06-30 (31.6.2018)

17. https://www.umb.sk/o-nas/informacie/o-univerzite/zakladne-principy-cinnosti-umb-a-uznavanehodnoty.html (31.7.2018)

\section{Броніслава Касачова, Даніела Гуффова \\ ДУМКИ СЛОВАКСЬКОГО АКАДЕМІЧНОГО ПЕРСОНАЛУ ТА СТУДЕНТІВ З ПРОФЕСІЙНИХ КОМПЕТЕНЦІЙ АКАДЕМІЧНИХ ВЧИТЕЛІВ}

У статті висвітлено результати порівняльного дослідження, проведеного в рамках проекту Міжнародного Вишеградського фонду № 21720008 у період з 2017 по 2018 рік. У проекті взяли участь чотири країни: Україна, Республіка Польща, Чеська Республіка і Словаччина. У рамках дослідження було вивчено думки вчителів і студентів університетів щодо компетенчій викладачів. Висвітлено особливості словацького погляду на компетенції викладачів та законодавство професійних компетенцій. Здійснено аналіз даних, отриманих в словацьких університетах, на основі зіставлення думок вчителів і студентів щодо компетенцій викладачів.

Ключові слова: академічний викладач, компетентність, порівняльне дослідження, професійна компетенція, професіографічні дослідження.

\section{Бронислава Касачова, Даниэла Гуффова}

\section{МНЕНИЯ СЛОВАКСКОГО АКАДЕМИЧЕСКОГО ПЕРСОНАЛА И СТУДЕНТОВ ПО ПРОФЕССИОНАЛЬНЫМ КОМПЕТЕНЦИЯМ АКАДЕМИЧЕСКИХ УЧИТЕЛЕЙ}

В статье освещены результаты сравнительного исследования, проведенного в рамках проекта Международного Вышеградского фонда № 21720008 в период с 2017 по 2018 год. В проекте приняли участие четыре страны: Украина, Республика Польша, Чешская Республика и Словакия. В рамках исследования были изучены мнения учителей и студентов университетов о компетенции преподавателей. Освещены особенности словацкого взгляда на компетенции преподавателей и законодательство профессиональных компетенций. Проанализированы данные, полученные в словацких университетах, на основе сопоставления мнений учителей и студентов о компетенции преподавателей.

Ключевые слова: академический преподаватель, компетентность, сравнительное исследование, профессиональная компетенция, профессиографические исследования.

Стаття надійшла до редакції 26.11.2018.

Прийнято до друку 29.11.2018. 